\title{
Nuclear medicine for photodynamic therapy in cancer: planning, monitoring and nuclear PDT
}

\author{
DrisKharroubiLakouas, MD ${ }^{1,2}$, Damien Huglo, $\mathrm{MD}, \mathrm{PhD},{ }^{1,2}$, Serge Mordon, $\mathrm{PhD},{ }^{1}$, Maximilien \\ Vermandel, $\mathrm{PhD},{ }^{1,2}$ \\ ${ }^{1}$ Univ. Lille, Inserm, CHU Lille, U1189 - ONCO-THAI - Image Assisted Laser Therapy for Oncology, F-59000 \\ Lille, France \\ ${ }^{2} \mathrm{CHU}$ Lille, Nuclear Medicine Department, F-59000, Lille, France
}

Corresponding author: m-vermandel@chru-lille.fr

\begin{abstract}
Photodynamic therapy (PDT) is a modality with promising results for the treatment of various cancers. PDT is increasingly included in the standard of care for different pathologies. This therapy relies on the effects of light delivered to photosensitized cells. At different stages of delivery, PDT requires imaging toplan, evaluate and monitor treatment. The contribution of molecular imaging in this context is important and continues to increase. In this article, we review the contribution of nuclear medicine imaging in oncology to PDT for planning and therapeutic monitoring purposes. Several solutions have been proposed to plan PDT from nuclear medicine imaging. For instance, photosensitizer biodistribution has been evaluated with aradiolabeled photosensitizer or with conventionalradiopharmaceuticals on positron emission tomography. The effects of PDT delivery have also been explored with specific SPECT or PET radiopharmaceuticals to evaluate the effects on cells (apoptosis, necrosis, proliferation, metabolism) or vascular damage. Finally, the synergy between photosensitizers and radiopharmaceuticals has been studied considering the Cerenkov effect to activate photosensitized cells.
\end{abstract}

Keywords: Photodynamic therapy, Oncology, PET, SPECT, 5-Aminolevulinic acid, PPIX

\section{Compliance with ethical standards}

Conflicts of interest: None

Funding: None

Ethical approval:This article does not contain any studies with human participants or animalsperformed by any of the authors. 


\section{Introduction}

Photodynamic therapy (PDT) is apromisingstrategy for cancer therapy ${ }^{1,2}$.PDT is a non-thermal treatment based on the synergy of three elements: the administration of a photosensitizer drug;light at a precise wavelength; and the presence of oxygen (Figure1). When these three components are combined, they lead to the formation of reactive oxygen species,resulting in a complex cascade of events and subsequent cell death, mainly via cytotoxic and vasculotoxicactivity.

Most of the time, PDT relies on a specific biodistribution of a photosensitizer drug to tumor cells. Amongphotosensitizer drugs, porphyrins are the most frequently used in the literature ${ }^{3,4}$.

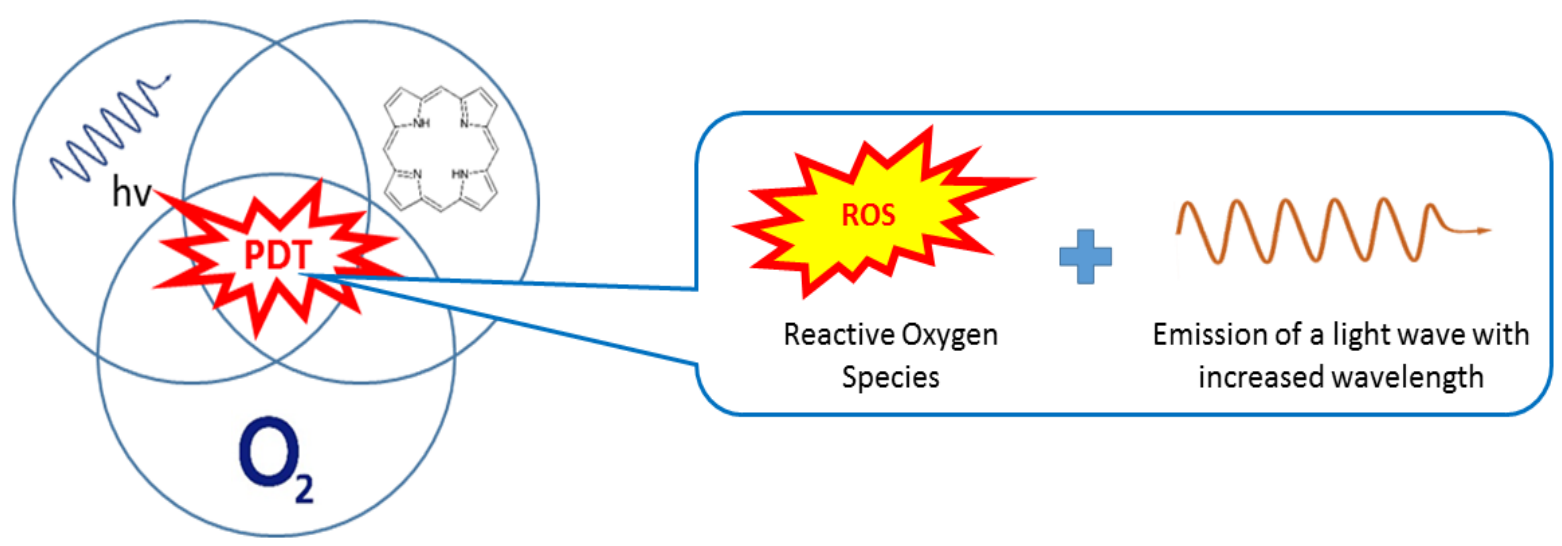

Figure 1:Illustration of the PDT mechanism, which is initiated by the combination ofa photosensitizer,a light wave, and oxygen. PDT activation produces cytotoxic effects andfluorescence emission.

Porphyrins are macrocyclic organic compounds that have been implicated in various biological functions; the most common porphyrins areheme and chlorophyll. In addition to their interesting biological functions, they havehigh intrinsic specificity for tumors,low toxicity and favorable photophysical properties, such asfluorescence (Figure 1$)^{5}$.

PDT was initially developed for dermatological lesions, which are easily accessible to light and can be monitored by visual assessment. Based on the success of this method and despite the low penetration of light in biological tissues, apromising method has been reported for the treatment of deep tumorsusing in situ inserted optical fibers ${ }^{6,7}$. This method is referred to as interstitial photodynamic therapy (iPDT). Therefore, to assess the photosensitizerbiodistribution and monitor the therapeutic response of deep tumors, imaging is essential. Molecular imaging is a promising and prime candidate for PDT planning and monitoring, and the photosensitizer biodistribution is a relevant issue for PDT planning that radiolabeled photosensitizers or conventional PET radiopharmaceuticals may address efficiently. Molecular imaging also plays a key role in the monitoring of PDT. Radiotracers currently in use for molecular imagingmay have applications in the evaluation ofPDT effects, such as apoptosis, hypoxia, perfusion or mitochondrial viability.

This article aims to present the increasing contribution of nuclear medicine imaging in oncology for the planning and monitoring of PDT and the therapeutic prospects of nuclear PDT.

\section{Photosensitizer biodistribution for photodynamic therapy planning}

PDTrelies on photosensitizer accumulation in a tumor, and some issues must be addressed prior to delivering treatment. Tumorsmay nothavesufficientphotosensitizer uptaketo enablePDT ${ }^{8,9}$, or the drug accumulation may be heterogeneous. To address theseissues and provide treatment planning solutions, 
both thedesign ofradiolabeled photosensitizersandmolecular radiotracersalready in use clinically are relevant.

\section{a. Radiolabeled porphyrins}

Porphyrinscanberadiolabeledvia simplecomplexationchemistry with their metallo-complex chelatoras interesting biomarkers for in vivo quantitative biodistribution ${ }^{5}$. Radiolabeling ofporphyrins was first achieved with copper-64 in $1951^{10,11}$. Hydrogen-3, carbon-14, palladium-109, sulfur-35, zinc-65, cobalt-57, andiodine-125have also been explored but are unsuitable for in vivo imaging because of their long half-lives or weak gamma photon energy. For scintigraphic imaging,neodymium-104, gallium-67, indium-111 andtechnetium-99m (99mTc), the most commonly usedisotope, have been evaluated $^{12-21}$.For positron emission tomography imaging, radiolabeling with iodine-124, copper-64 and zinc-62 have been studied extensively ${ }^{5,10,22-27}$.In general, radiolabeled porphyrinsaccumulate in the tumor as standard porphyrins without altering the main characteristics of the host porphyrin molecules. Consequently, labeling using metal complexes of porphyrins is the most promising method ${ }^{5}$. A new metal isotope well-suited forhumanPET imaging, gallium-68, is now readilyavailable. Based on the simple complexationchemistry with the porphyrin core andinexpensive germanium-68/gallium-68 radionuclide generator system, thisisotopemight become the prime isotope for radiolabeling porphyrins ${ }^{28-31}$.Unfortunately, despite severalproposals forpersonalized planning of PDT $^{1,5,12,19,20}$, radiolabeled porphyrins havenotbeen studied for theprediction or quantitative assessment of photosensitizeruptake, probably because, until recently, PDT was limited to superficial tumorsin which photosensitizer uptake is assessable by visual fluorescence.However, acommercialized photosensitizer for PDT, such as Photosan-3®(SeehofLaboratorium F\&E GmbH, Wesselburenerkoog, Germany), successfully radiolabeled ${ }^{12,21}$ with $99 \mathrm{~m}$-technetitum might be evaluated to individualize PDT treatment protocols.

\section{b. Photosensitizer prodrug: the case of 5-aminolevulinic acid}

5-Aminolevulinic acid (5-ALA) is a prodrug compound that is biologically inactive and preferentiallyaccumulatesin tumor cells, whereit is transformed into protoporphyrin IX (PpIX) with ahightumor/surrounding healthy tissue ratio, particularly for glioblastoma. Hence, 5-ALA induces the selective accumulation of PpIX in tumor tissues. Consequently, 5-ALA is mainly used in clinical practice for fluorescence-guided resection of glioma to facilitate more complete resection compared with conventional surgery ${ }^{32}$. Objective responses have been observed for the treatment of nonmelanoma skin cancer, gastrointestinal adenocarcinoma, bladder cancers, and gliomawith PDT using $5-\mathrm{ALA}^{2,9,33}$.Despite the high intrinsic specificity of PpIX for tumors, PpIX may be absent from the tumor or distributed heterogeneously, and an accurate assessment ofPpIX accumulationis expected topredict PDTefficacy. Although fluorescence imaging is ideal to assess the presence of PpIXafter 5ALA administration, it is not always achievable for deep tumors. In response,radiolabeled 5-ALA compounds were recently developed. 5-Amino-4-oxo-[6-11C]hexanoic acid (11C-MALA) can be used to evaluate the quantitative accumulation and spatial distribution of 5-ALA in tumor tissues ${ }^{9,34}$, and forimproved clinicalavailability, 99m-technetium-5-aminolevulinic acidwas synthesized $^{33}$.However,the potential correlation between the tumorbiodistribution of 5-ALA and PpIX remains unclear and warrants further study.

\section{c. Common PETradiopharmaceuticals}

For certain pathologies, molecular imagingis more suitableto definetumor volumethan conventionalimaging, especially for neurosurgery or radiotherapy ${ }^{35-37}$. For example, PDT planning including 18F-fluorodeoxyglucose PET (18F-FDG PET) has been proposed for head and neck cancers $^{38}$. However, very few studies have comparedtheaccumulated amount of photosensitizer drug 
as a function of the target volume defined by PET imaging. Studies comparing gadoliniumdiethylenetriaminepentaacetic acid (Gd-DTPA) in Magnetic Resonance Imaging (MRI), 18Ffluoroethyl-L-tyrosine (18F-FET) PET, and 5-ALA tumorbiodistribution for glioma, glioblastoma and meningioma $^{8,39-42}$ have demonstrated that metabolic imaging with 18F-FETis superior to Gd-DPTA enhancement in MRI for predicting thedistribution of 5-ALA in glioblastoma, with a very high accuracy of $96 \%$ and a negative predictive value of $100 \% \%^{8,39}$. Thus, 18F-FET PET is an importanttool for PDT in the brain,where the local fluorescence of PpIXcannot be observed. However, no study has compared the tumor distribution of 5-ALA to that of 3,4-dihydroxy- $6-{ }^{18} \mathrm{~F}$-fluoro-l-phenylalanine $(18 \mathrm{~F}$ FDOPA), although the latter exhibits abetter ratio of brain tumor/healthy tissue with Carbidopa premedicationthan $18 \mathrm{~F}-\mathrm{FET}^{43}$. However, these studies also showed that the accuracy of 18F-FET to predict the 5-ALA tumor distribution decreased for low-grade glioma. These results are not due to the failure of 18F-FET PET but confirm that 5-ALA and porphyrins in generalare sensitive to tumor grade $^{8}$. Porphyrin accumulation depends on the type of cancer and especially on the degree of differentiation ${ }^{9,44}$. For gliomas, 18F-FET quantitative accumulation is correlated with tumorgrade, and18F-FDGaccumulation is inversely correlated to tumor differentiation. For high-grade and dedifferentiatedtumors, the glucose metabolism observed on 18F-FDG PET may be correlated withphotosensitizer accumulation. In this context, an in vitro study demonstrated that 18F-FDG uptake before PDT can predicttreatment efficacy ${ }^{45}$. This last point deserves further exploration.

\section{Photodynamic therapy monitoring}

Monitoring is required to evaluate the treatment response. In the early stage, monitoring enables adaptation of delivery in case of an inadequate response or the prediction of long-term response. Monitoring is generally accomplished using specific biomarkersto estimate the evolution of the disease.Tumorfluorescencecan be considereda biomarkerfor monitoringtreatment response when considering superficial tumors. However, as for the study of the biodistribution of photosensitizer drugs, fluorescence cannot be used for deep tumors. Several studies have proposed to address this problemby including metabolic imaging inPDT protocols to provide biomarkers and prognostic factorsto predicttreatment response earlier than morphological imaging ${ }^{1,5,19,20}$.

Radiolabeledporphyrinsformonitoringafter PDThave been suggested but have not been investigated further ${ }^{1,5,19,20}$. The maindrawback might betheloss ofsensitivityaftertreatmentbecause tumor cellsselectedby PDT will no longer accumulatethe photosensitizer. Consequently, monitoringusing non-specificradiotracersseemsmore appropriate and convenient.

PDT induces a selective tumor response through different mechanisms. The effectivenessand preponderance ofcertain mechanismscompared to othersis influencedby the illuminationprotocol,includingthe fluence and fractionation, bytissue oxygenation, and,obviously,by the type ofphotosensitizer drug $^{2,46}$. The mainmechanisms areimpairment of tumor vascularization and direct cell death by apoptosis and necrosis.Therefore, different PDTeffects maybe observedwith different radiotracers. The radiotracers presented in the following are of interest for monitoring PDT. These data are from preclinical studies and depend on the tumor models and therapeutic protocols (Table 1).

\section{a. Glucose metabolismwith 18F-fluorodesoxyglucose}

The glucose analogue18F-FDGenters tumor cellsvia theoverexpressed membrane transporter GLUT and accumulates by phosphorylation in the cytoplasm. This very common radiopharmaceutical can be used to observe bothtissue perfusion in minutes followingintravenous administrationandglucose metabolism in an equilibrium state (a minimum of $15 \mathrm{~min}$ post injection). When used afterPDT,18FFDG PETshows the treatment responseearlier thanmorphological imaging. As early as 30 minutes and $2 \mathrm{~h}$ after PDT, clear decreases in tumor perfusion and glucose metabolism due to the destruction of the 
vascular system and direct cell death ${ }^{47,48}$ were observed. At 24 and 48 hafterPDT,18F-FDG PET imagingshowed,inmost cases,adecrease in tumormetabolism ${ }^{48,49}$. Although one study showed an increase in tumor metabolic activity $24 \mathrm{~h}$ after PDT, the type of photosensitizer drug used might be responsible for this increase. The authors suggested hypermetabolism of the photosensitizerdrug, a porphyrin-monoclonal antibody conjugate, at 24 hpostPDTvia a probable acute inflammatory response $^{49}$. Finally, $36 \mathrm{~h}$ afterPDT, the metabolic volume on18F-FDG PETdescribed the absolute volume of the survivingtumor histological massat a resolution similar to that of MRI, revealing the early extended injury caused by PDT $^{50}$.

\section{b. Protein metabolismwith 18F-fluoroethyltyrosine and 18F- fluorodihydroxyphenylalanine (18F-FDOPA)}

The radiolabeled amino acids 18F-FET and 18F-fluorodihydroxyphenylalanine (18FDOPA)aremainly used for studies of brain tumors, in which these amino acids accumulate with excellent contrast compared to that in healthy tissuethanks to their ability to freely cross the bloodbrain barrier and the overexpression of LATtransporters by tumor cells. No study has described the monitoring of PDT with these radiopharmaceuticals, but these amino acids are ofparticularinterestfor monitoring other treatments, especially for brain tumors. 18F-DOPA and 18F-FET are used for brain tumors inclinical practice by default with MRI, particularly to differentiate tumor progression from radionecrosis after glioma radiotherapy. Thus, radiolabeled amino acidscould certainlybeused to differentiatetumor progressionfrom the tumorphotonecrosisinducedbyPDT.

\section{c. Tumor proliferation with $18 \mathrm{~F}$-fluorodeoxythymidine}

18F-fluorodeoxythymidine (18F-FLT), a thymidine analogue, is trapped in cells and is phosphorylated by the cytosolic thymidine kinase-1, an enzyme of the pyrimidine salvage pathway of DNA synthesis. This radiopharmaceuticalenables imagingoftumor proliferation. In two studies, 18F-FLT PETshowed an early responseto treatment with clearhypometabolism4hand 24hafterPDT ${ }^{51,52}$. Interestingly,afterPDT, the decrease in metabolic proliferativeactivityobserved using 18F-FLT PETappears to bemore pronouncedthan the decreased metabolism glucose activity observed by $18 \mathrm{~F}$ FDG PET ${ }^{51}$.

\section{d. Membranerenewal with $11 \mathrm{C}$-choline}

The phosphorylation of choline is catalyzed by choline kinase, whichis overexpressed in tumor cells.Phosphorylcholineis incorporated into phosphatidylcholine, a component of the cell membrane.Thus, cholineradiolabelingpermits imagingoftumormembranerenewal. There is interest in following theearlyresponse ofprostatecancer to PDT. From 1 to $48 \mathrm{~h}$ after therapy, PET imaging with 11C-choline revealed a marked decrease intumor $11 \mathrm{C}$-choline uptake ${ }^{53,54}$. 11C-Choline hasnot been studiedin PDT monitoringforother cancers, and the radiolabeledforms with fluorine-18 (18Ffluoromethylcholine and 18F-fluoroethylcholine) have not been studied either.

\section{e. Apoptosis, 64-Cu-DOTA-biotin-Sav and 99-mTc-AnnexinV}

Apoptosis isa mechanism of cell deathinduced byPDT and occurs very early,within the first hourfollowingPDT ${ }^{2}$. Because it is tolerated betterdue to less tissue inflammation,apoptosis is the preferred cell death mechanism when choosing the photosensitizer drug and lighting method for PDTprotocols. There are radiotracers for theapoptosis target phosphatidylserine, which is externalized by apoptotic cells. PETimaging using 64Cu-DOTA-biotin-Sav showed clear uptake within hours following PDT, from $4.5 \mathrm{~h}$ post PDT.The amount of timeto reach optimal contrast after PDTdepends onthe type ofphotosensitizerdrugused and ranges from6-7 hto 10-11 hpostPDTfor two differentphotosensitizerdrugs.However,the laborious protocol required prior to theinjectionof the radiotracer,which includes pretargeting with biotinylated annexin $\mathrm{V}$,followed by anavidin chase to eliminate free biotinylated products, is an important drawback of the use of this radiopharmaceutical. 
Moreover,the isotope 64-copperdoes not haveideal properties for diagnostic use in humans ${ }^{55}$. Another apoptosis radiotracer used in SPECT imaging, 99m-Tc-Annexin V, was tested for PDT. 99m-TcAnnexin V might be well-suited for clinical use because it can beeasily preparedwithin theclinical departmentofnuclearmedicine,does notrequirepretargetingsteps, and isperfectly suitedfor human use. Excellent uptake of $99 \mathrm{mTc}$-Annexin $\mathrm{V}$ was observed in treated tumors 2,4 and $7 \mathrm{~h}$ after PDT, as confirmed by histology ${ }^{56}$.

\section{f. Hypoxia with 123I-iodoazomycin arabinoside}

Although more recent PET radiotracers of hypoxia are available, 123I-iodoazomycin arabinoside (123I-IAZA) isthe only radiotracer that has been studied for post-PDT monitoring. 123I-IAZA is metabolically reduced in viable cells and is inversely proportional to the intracellular oxygen concentration. 123I-IAZA exhibits significant accumulation 24h after PDT,concordant with a decrease intissue perfusion ${ }^{57}$.

\section{g. Perfusion and mitochondrial viability with 99mTc-hexakis-2-methoxyisobutyl isonitrileor 99mTc-hexamethylpropyleneamine oxime}

The cationic complex 99mTc-hexakis-2-methyoxyisobutyl isonitrile (99mTc-MIBI) is retained by the mitochondria mainly due to its lipophilicity and charge. The uptakeof 99mTc-MIBI depends on the mitochondrion membrane potential and thus reflects mitochondrial viability. This complex was initially developed to visualize myocardial perfusion using scintigraphic imaging. The use of $99 \mathrm{mTc}-$ MIBI to assess tumor vascular perfusion after PDT revealed that tumor vascular perfusion decreased dramatically during the 2-h period following PDT and continued to decrease to $7 \%$ of the control value $24 \mathrm{~h}$ later ${ }^{58,59}$.Another radiopharmaceutical for perfusion is $99 \mathrm{mTc}$-hexamethylpropyleneamine oxime (99mTc-HMPAO), a liposoluble molecule that diffuses into the cell and then becomes hydrophilic and remains trapped in the cytoplasm. Tumor perfusion can be assessed to evaluate the vascular damage mechanism of PDT. Monitoring of PDT with 99mTc-HMPAO revealed maximal shut-down $8 \mathrm{~h}$ post treatment, which persisted for at least $24 \mathrm{~h}^{57,60}$. Regardless of tissue perfusion, $99 \mathrm{mTc}-\mathrm{MIBI}$ is particularly interesting because some photosensitizers,such as Photofrin ${ }^{\circledR}$, target the mitochondria.Therefore,99mTc-MIBI doesreveal destruction of mitochondria by the free radicals produced by PDT. The role of the mitochondria in the apoptosis mechanism could explain the apoptotic action of PDT.Accordingly, an in vitro study demonstrated that $99 \mathrm{mTc}-\mathrm{MIBI}$ is superior to 18F-FDG for monitoring PDT, demonstrating a linear correlation with cell viability ${ }^{45}$.

\begin{tabular}{|c|c|c|c|c|c|c|}
\hline Author & Radiotracer & $\begin{array}{c}\text { Tumor } \\
\text { histology }\end{array}$ & Photosensitizer & $\begin{array}{c}\text { Effect } \\
\text { evaluated }\end{array}$ & $\begin{array}{l}\text { Time to } \\
\text { significant } \\
\text { effect }\end{array}$ & Model \\
\hline $\begin{array}{l}\text { D. Lapointe } \\
\text { et al. } 1999^{47}\end{array}$ & $\begin{array}{l}\text { Bolus }{ }^{18} \mathrm{~F}- \\
\text { FDG }\end{array}$ & $\begin{array}{l}\text { EMT6 } \\
\text { murine } \\
\text { mammary }\end{array}$ & PII and AlPcS & $\begin{array}{l}\text { Glucose } \\
\text { metabolis } \\
\mathrm{m}\end{array}$ & $30 \mathrm{~min}$ & Mice \\
\hline $\begin{array}{l}\text { AT. Byrne } \\
\text { et al. } 2009^{48}\end{array}$ & $\begin{array}{l}\text { Bolus }{ }^{18} \mathrm{~F}- \\
\text { FDG }\end{array}$ & $\begin{array}{l}13762 \text { MAT } \\
\text { B III rat } \\
\text { mammary }\end{array}$ & ADMP06 & $\begin{array}{l}\text { Glucose } \\
\text { metabolis } \\
\mathrm{m}\end{array}$ & 30min & Rats \\
\hline $\begin{array}{l}\text { K. Smith et } \\
\text { al. } 2010^{49}\end{array}$ & $\begin{array}{l}\text { Bolus }{ }^{18} \mathrm{~F}- \\
\text { FDG }\end{array}$ & $\begin{array}{l}\text { LoVohuman } \\
\text { colon } \\
\text { adenocarcin } \\
\text { oma }\end{array}$ & $\begin{array}{l}\text { Anti-CD104- } \\
\text { isothiocyanato } \\
\text { porphyrin } \\
\text { conjugate }\end{array}$ & $\begin{array}{l}\text { Glucose } \\
\text { metabolis } \\
\mathrm{m}\end{array}$ & $24 \mathrm{~h}$ & Mice \\
\hline
\end{tabular}




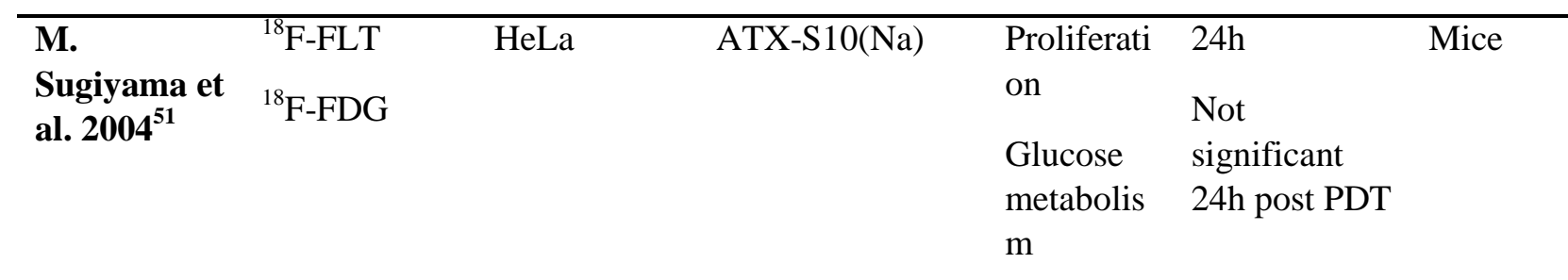

\begin{tabular}{|c|c|c|c|c|c|c|}
\hline $\begin{array}{l}\text { AE. } \\
\text { O'Connor } \\
\text { et al. } 2012^{52}\end{array}$ & ${ }^{18} \mathrm{~F}-\mathrm{FLT}$ & $\begin{array}{l}\text { MDA-MB- } \\
231-T G L \\
\text { human } \\
\text { mammary } \\
\text { and U87- } \\
\text { TGL human } \\
\text { glioma }\end{array}$ & ADPM06 & $\begin{array}{l}\text { Proliferati } \\
\text { on }\end{array}$ & $4 \mathrm{~h}$ & Mice \\
\hline $\begin{array}{l}\text { B. Fei et al. } \\
2010^{53}\end{array}$ & ${ }^{11} \mathrm{C}$-Choline & $\begin{array}{l}\text { PC-3 and } \\
\text { CWR22, } \\
\text { two human } \\
\text { prostate }\end{array}$ & $\operatorname{Pc} 4$ & $\begin{array}{l}\text { Membran } \\
\text { erenewal }\end{array}$ & $24 \mathrm{~h}$ & Mice \\
\hline
\end{tabular}

$\begin{array}{lllllll}\begin{array}{l}\text { B. Fei et al. } \\ \text { 2009 }^{\text {54 }}\end{array} & { }^{11} \text { C-Choline } & \begin{array}{l}\text { PC-3 human } \\ \text { prostate }\end{array} & \text { Pc } 4 & \begin{array}{l}\text { Membran } \\ \text { erenewal }\end{array} & 48 \mathrm{~h} & \text { Mice } \\ \begin{array}{lllll}\text { N. Cauchon } \\ \text { et al. 2007 }\end{array} & \begin{array}{l}{ }^{64} \mathrm{Cu}-\mathrm{DOTA}- \\ \text { biotin-SAv }\end{array} & \begin{array}{l}\text { EMT6 } \\ \text { murine } \\ \text { mammary }\end{array} & \begin{array}{l}\text { ZnPcS2 and } \\ \text { AlPcS2 }\end{array} & \text { Apoptosis } & 4.5 \mathrm{~h} & \text { Mice } \\ & & & & & \end{array}$

\begin{tabular}{|c|c|c|c|c|c|c|}
\hline $\begin{array}{l}\text { M. } \\
\text { Subbarayan } \\
\text { et al. } 2003^{56}\end{array}$ & $\begin{array}{l}{ }^{99 \mathrm{~m}} \mathrm{Tc}- \\
\text { annexin } \mathrm{V}\end{array}$ & $\begin{array}{l}\text { RIF-1 } \\
\text { murine } \\
\text { fibrosarcom } \\
\text { a }\end{array}$ & $\operatorname{Pc} 4$ & Apoptosis & $2 \mathrm{~h}$ & Mice \\
\hline \multirow{2}{*}{$\begin{array}{l}\text { RB. Moore } \\
\text { et al. } \text { 1993 }^{57}\end{array}$} & ${ }^{123} \mathrm{I}-\mathrm{IAZA}$ & \multirow{2}{*}{$\begin{array}{l}\mathrm{R} 3327-\mathrm{AT} \\
\text { rat prostate }\end{array}$} & \multirow[t]{2}{*}{ PII } & Hypoxia & $24 \mathrm{~h}$ & \multirow[t]{2}{*}{ Rats } \\
\hline & $\begin{array}{l}\text { 99mTc- } \\
\text { HMPAO }\end{array}$ & & & $\begin{array}{l}\text { Vascular } \\
\text { damage }\end{array}$ & $24 \mathrm{~h}$ & \\
\hline $\begin{array}{l}\text { WS. Chan } \\
\text { et al. } 1997^{58}\end{array}$ & ${ }^{99 \mathrm{~m}} \mathrm{Tc}-\mathrm{MIBI}$ & $\begin{array}{l}\text { EMT6 } \\
\text { murine } \\
\text { mammary }\end{array}$ & $\begin{array}{l}\mathrm{AlPc}, \mathrm{AlPcS} 21 \\
\text { and } \mathrm{AlPcS} 2\end{array}$ & $\begin{array}{l}\text { Vascular } \\
\text { damage }\end{array}$ & $3 \mathrm{~h}$ & Mice \\
\hline $\begin{array}{l}\text { N. Brasseur } \\
\text { et al. } 1996^{59}\end{array}$ & ${ }^{99 \mathrm{~m}} \mathrm{Tc}-\mathrm{MIBI}$ & $\begin{array}{l}\text { EMT6 } \\
\text { murine } \\
\text { mammary }\end{array}$ & PII & $\begin{array}{l}\text { Vascular } \\
\text { damage }\end{array}$ & $\begin{array}{l}\text { Immediately } \\
\text { post PDT }\end{array}$ & Mice \\
\hline $\begin{array}{l}\text { RB. Moore } \\
\text { et al. } 1992^{60}\end{array}$ & $\begin{array}{l}{ }^{99 m} \text { Tc- } \\
\text { HMPAO }\end{array}$ & $\begin{array}{l}\text { R3327-AT } \\
\text { and R3327- } \\
\text { H rat } \\
\text { prostate }\end{array}$ & PII & $\begin{array}{l}\text { Vascular } \\
\text { damage }\end{array}$ & $8 \mathrm{~h}$ & Rats \\
\hline
\end{tabular}

Table 1:Preclinical studies on monitoring PDT with radiopharmaceuticals.

\section{Real time photodynamic therapy monitoring with dynamic PET}

A new promising method to study tumorresponsein real timehas recently been proposed to detect transient changes in uptake during treatment. This method consists of PDT applied during a dynamic 
PET study, with multipleshortframes reconstructed from list-mode data and a slow continuous infusion of 18F-FDG. Because of the continuous infusion, the 18F-FDG concentration does not reach an equilibrium state, but its rate of increase is constant. Thus, the effects of the treatment are observed in real time based on the kinetics of the radiopharmaceutical ${ }^{48,61,62}$. As previously explained,PDTacts via different mechanismsdepending on the photosensitizer drug type. The two mainmechanismsare direct cell death andimpairment of the tumor vascularization. These mechanisms can be distinguished by real-time dynamic PET (Figure 2). Thus, damage totumor vascularizationischaracterized by a delayed drop in tumor uptakethat remains significantly lower after illumination ends. Direct cell death is characterized by a rapid reduction of 18F-FDG uptake followed by rapid restoration to more than $80 \%$ of the initial rate after illumination ends. Interestingly, thisnew method has led to the discovery of a systemic response to PDT because control tumors shielded from light alsoshowed reduced 18F-FDG uptake during the illumination phase ${ }^{61}$.However,othermechanismsmight have affectedthe kineticsof $18 \mathrm{~F}-\mathrm{FDG}$, such as apoptosis and the inflammatory response in the tumors. Selective apoptosis is a desired response to PDT, whereas inflammation is often a side effect. Recent studies have shown that a low-fluence illumination protocol is more effective and better tolerated thanks to a greater apoptotic process and less inflammation ${ }^{63,64}$. Dynamic PET during PDT might also be explored to compare the metabolic responsesto low and high fluence rates but remains to be studied.

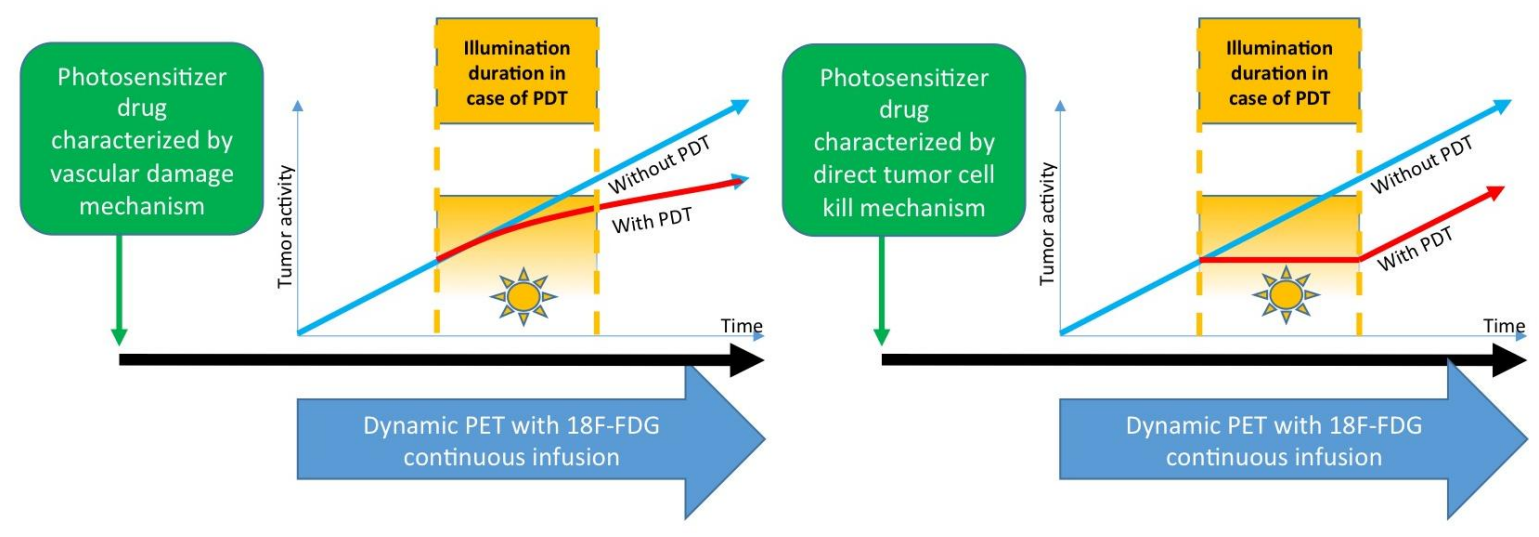

Figure 2: Illustration of the vascular damage mechanism and the direct tumor cell killing mechanism observed in real time by dynamic PET. On the left, the effect of PDT with a photosensitizer inducing vascular damage ischaracterized by a delayed drop in tumor uptake, followed by a long recovery period after the illumination ends. On the right, theeffect of PDT with a photosensitizer inducing direct cell death is characterized by a rapid reduction in $18 \mathrm{~F}-\mathrm{FDG}$ uptake, followed by a rapid restoration after the illumination ends ${ }^{61}$.

\section{Discussion and Perspectives}

Molecular imaging mightfacilitate PDT planning by predicting the quantitative biodistribution of thephotosensitizer in thetumor.In particular, a new metal isotope for PET imaging, 68-gallium,offers easy radiolabeling using its metal complexes andholds promise for PDT planning ${ }^{5}$. Indeed, the simple complexationchemistry of 68-gallium with the porphyrin core andgood availability asthe relatively low-cost 68-germanium/68-gallium radionuclide generator system is highly suitable for radiolabeled porphyrins ${ }^{28-31}$. Given the importance of tumor oxygenation for the effectiveness of PDT, it is surprising that there has been no study of the ability of 123I-IAZA or other radiotracers of hypoxia to predict and follow the response to PDT.Imaging hypoxia prior to the delivery of PDT might be akey issuefor adapting dosimetry (fractionation scheme, fluence rate, total dose).

However, radiolabeled porphyrins might not be suitable for monitoring the effect of PDT, and nonspecificmetabolic radiotracers might be preferable. Themainmechanisms observed after PDT are damage totumor vascularization and direct cell death caused by apoptosis and necrosis. Therefore, 
different PDTeffects maybe observedusing different metabolic radiotracers routinely used in nuclear medicine.

Moreover, real-time 18F-FDG PET during PDT can assess PDT protocols in real time and thus enable optimizationof their duration,oxygenation, andillumination to achievepersonalized treatment. Consequently, monitoring PDT by dynamic PET could be a major advance in therapy. Thus, nuclear medicine, thanks to molecular imaging, offers interesting perspectives to optimize and personalize PDT.

However, the contribution of nuclear medicine is not limited only to PDT accompaniment but could also include PDT in deep tumorsas an alternative tointerstitial PDT. This so-called nuclear PDT relies on the Cherenkov effect as an alternative light source for PDT in deep tissue.Cherenkov radiation is an optical emission induced when charged particles move faster than the speed of light in a dielectric medium. This phenomenon is well known in the nuclear energy industry as it is responsible for the blue glow of an underwater nuclear reactor. The threshold energy of $\beta$-particles (electrons) to produce Cherenkov radiation in tissues is $0.219 \mathrm{MeV}$. High-energy photons can also indirectly produce Cherenkov radiation by secondary electrons caused by photoelectric interaction or Compton scattering ${ }^{65}$. Several isotopes used in radiopharmaceuticals emit particles with a greater energy than the threshold of $0.219 \mathrm{MeV}$ and thus produce Cherenkov radiation ${ }^{66-68}$. Several recent studies have examined Cherenkov luminescence tomography, including in small animals ${ }^{69-71}$.Cherenkov radiation is ofparticular interest for PDT because it provides a deep light source without an invasive device. Cherenkov radiationisalso perfectly adapted to PDT with 3 major benefits: proven efficacy and better tolerance of ultra-low fluence rate excitation during PDT ${ }^{63,72}$, with a meaningful effect at a $12 \mathrm{~mJ} / \mathrm{cm}^{2}$ threshold with a second-generation photosensitizer ${ }^{73}$; blueluminescenceoptimal for the activation of porphyrins ${ }^{1,74}$ (Figure 3 ); and light production inside the tumor.In vivo photoactivation using Cherenkov from 18FDG has been demonstrated as a proof of concept $^{75}$, and tumor remission was achieved using aphotosensitizeractivated by Cherenkovradiation from radionuclides ${ }^{76,77}$. Isotopes with a longer half-life and emitting particles withgreater energy, such as 90Yttrium used in clinicaloncology for the treatment of lymphoma (radioimmunotherapywith Zevalin ${ }^{\circledR}$ ) and hepatocellular carcinoma (radioembolizationwith SirSpheres ${ }^{\circledR}$ or TheraSphere ${ }^{\circledR}$ ), could deposit an adequate total Cherenkov light dose for $\mathrm{PDT}^{72}$. Thus, the synergy between internal radiotherapy and PDTwarrants further investigation (Figure4). 


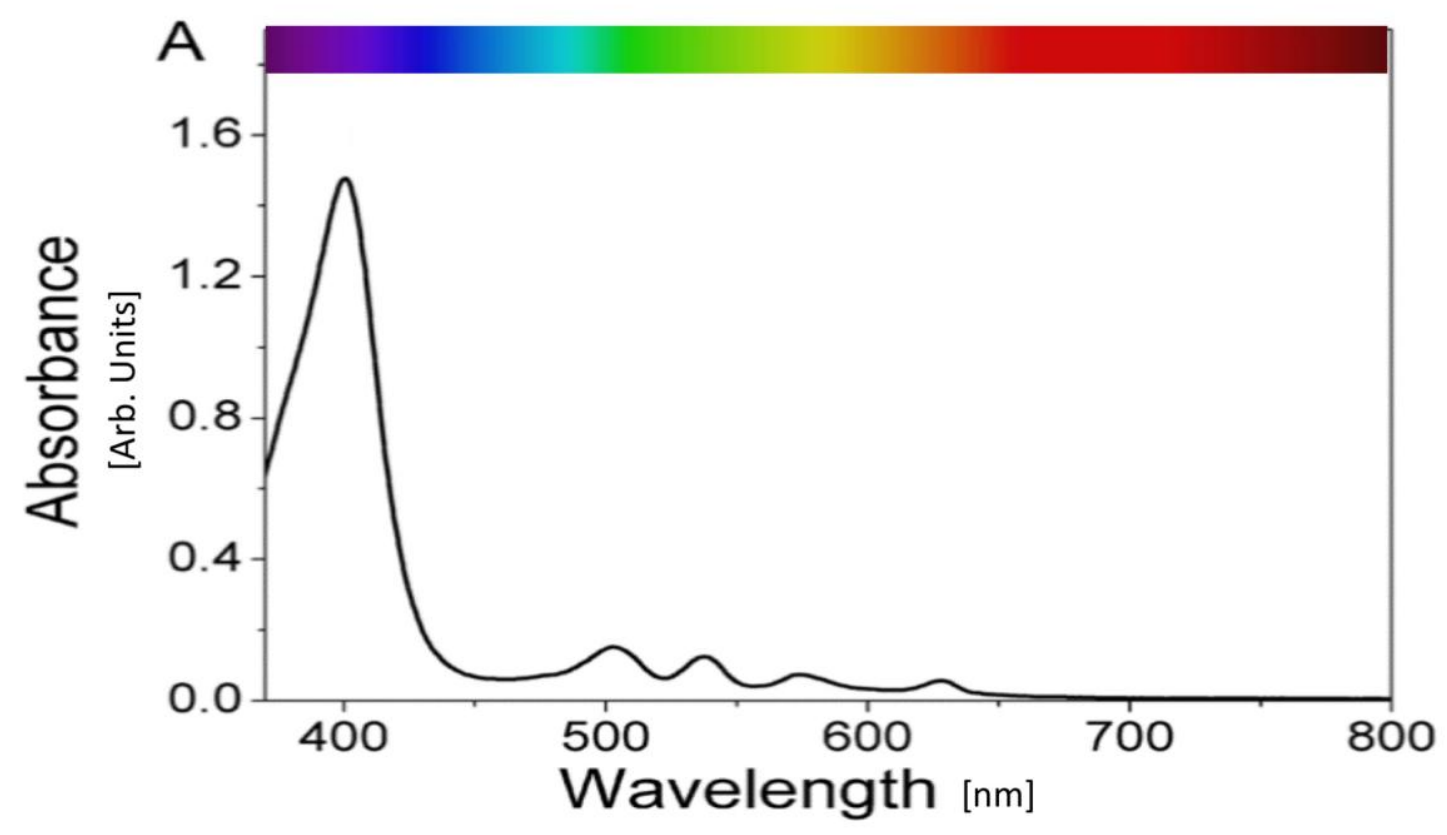

Figure 3: Absorption spectrum of protoporphyrin IX (PpIX).
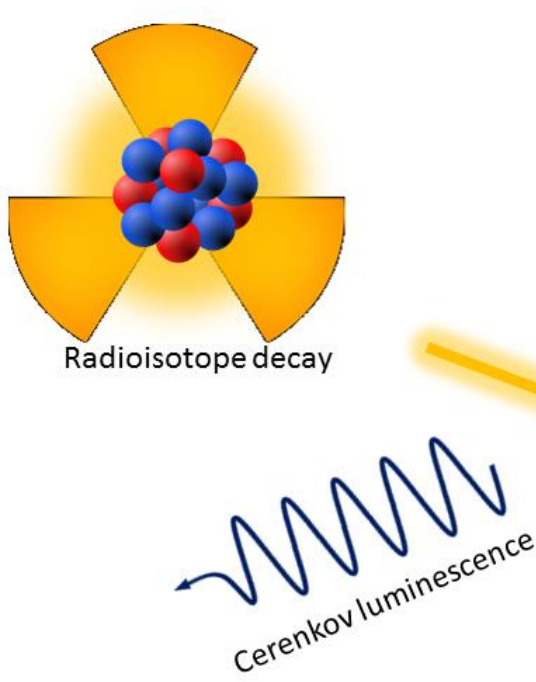
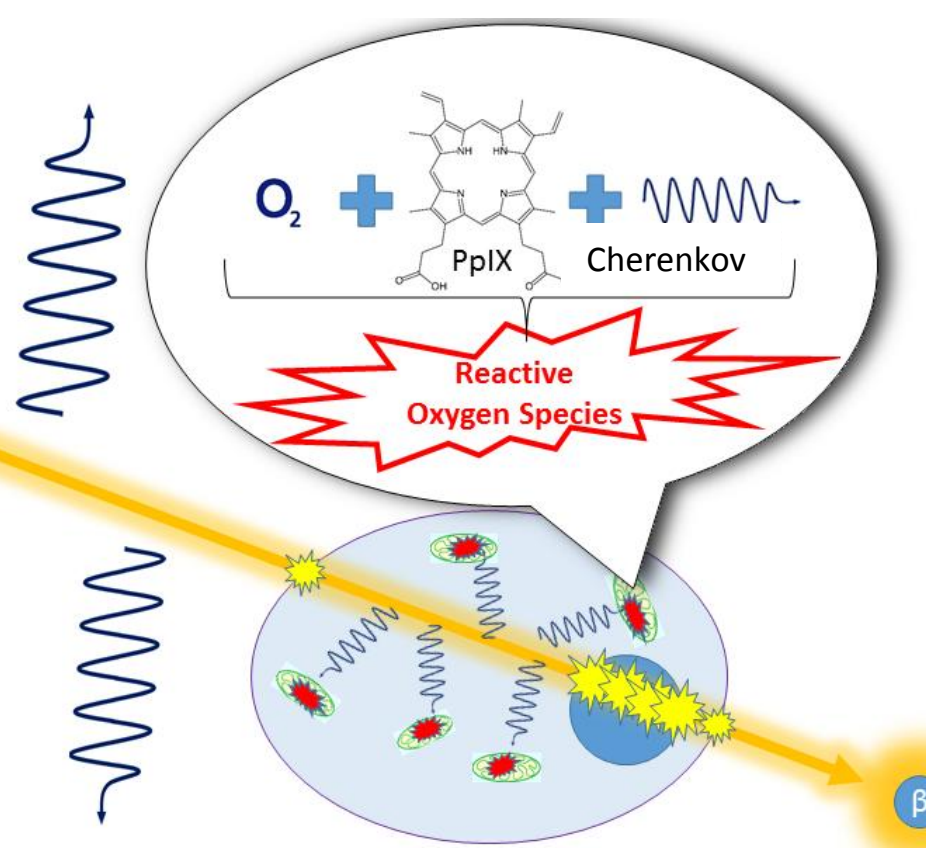

Tumor cell damage

Figure 4: Illustration of nuclear PDT and the synergy between internal radiotherapy and photodynamic therapy.

\section{Conclusion}

Nuclear medicine is essential in oncology. It is an indispensable tool for a variety of current therapiesand is also an asset forPDT. The simplicity and effectiveness of porphyrinradiolabeling, its low toxicity and its accumulation intumor tissues make it a potentialtheranosticagent. The contributionof nuclear medicine is not limited to monitoring and might include the estimation of 
photosensitizeruptake in deeptumors for improved treatment planning, the identification of various biologicalmechanismsof treatment andtheir effectivenessin real time, andas an optimal Cherenkov light sourceinside deep tumors.

\section{References:}

1. Josefsen LB, Boyle RW. Unique diagnostic and therapeutic roles of porphyrins and phthalocyanines in photodynamic therapy, imaging and theranostics. Theranostics. 2012;2(9):916-966. doi:10.7150/thno.4571.

2. Agostinis P, Berg K, Cengel K a, et al. Photodynamic Therapy of Cancer: An Update. Am Cancer Soc. 2011;61:250-281. doi:10.3322/caac.20114.Available.

3. Debele T, Peng S, Tsai H-C. Drug Carrier for Photodynamic Cancer Therapy. Vol 16.; 2015. doi:10.3390/ijms160922094.

4. Pushpan SK, Venkatraman S, Anand VG, et al. Porphyrins in photodynamic therapy - a search for ideal photosensitizers. Curr Med Chem Anticancer Agents. 2002;2(2):187-207. http://www.ncbi.nlm.nih.gov/pubmed/12678743.

5. Shi J. Transforming a Targeted Porphyrin Theranostic Agent into a PET Imaging Probe for Cancer. Theranostics. 2011:363. doi:10.7150/thno/v01p0363.

6. Bechet D, Mordon SR, Guillemin F, Barberi-heyob MA. Photodynamic therapy of malignant brain tumours : A complementary approach to conventional therapies. Cancer Treat Rev. 2014;40(2):229-241. doi:10.1016/j.ctrv.2012.07.004.

7. Quirk BJ, Brandal G, Donlon S, et al. Photodynamic therapy (PDT) for malignant brain tumors - where do we stand? Photodiagnosis Photodyn Ther. 2015:1-15. doi:10.1016/j.pdpdt.2015.04.009.

8. Floeth FW, Sabel M, Ewelt C, et al. Comparison of 18 F-FET PET and 5-ALA fluorescence in cerebral gliomas. Eur J Nucl Med Mol Imaging. 2011;38:731-741. doi:10.1007/s00259-0101690-z.

9. Suzuki C, Tsuji AB, Kato K, et al. Preclinical Characterization of 5-Amino-4-Oxo-[6-11 C] Hexanoic Acid as an Imaging Probe to Estimate Protoporphyrin IX Accumulation Induced by Exogenous Aminolevulinic Acid. J Nucl Med. 2015;55:1671-1678. doi:10.2967/jnumed.114.145086.

10. Waghorn P a. Radiolabelled porphyrins in nuclear medicine. J Label Compd Radiopharm. 2013;(October 2013). doi:10.1002/jlcr.3166.

11. Frank R. Wrenn, Myron L . Good PH. The Use of Positron-Emitting Radioisotopes for the Localization of Brain Tumors. Science (80- ). 1951;113(2940):525-527.

12. Babbar a. K, Singh a. K, Goel HC, Chauhan UPS, Sharma RK. Evaluation of 99mTc-labeled photosan-3, a hematoporphyrin derivative, as a potential radiopharmaceutical for tumor scintigraphy. Nucl Med Biol. 2000;27(6):587-592. doi:10.1016/S0969-8051(00)00123-2.

13. Maric N, Chan SM, Hoffer PB, Duray P. Radiolabeled porphyrin vs gallium-67 citrate for the detection of human melanoma in athymic mice. Int J Rad Appl Instrum B. 1988;15(5):543-551. doi:10.1016/S0969-8051(88)80013-1.

14. Foster N, Woo D V, Kaltovich F, Emrich J, Ljungquist C. Delineation of a transplanted malignant melanoma with indium-111-labeled porphyrin. J Nucl Med. 1985;26(7):756-760.

15. Robinson GD, Alavi a, Vaum R, Staum M. Imaging of lymph node uptake after intravenous administration of indium-111 metalloporphyrins. J Nucl Med. 1986;27(2):239-242.

16. Fazaeli Y, Jalilian AR, Amini MM, et al. Preparation and preliminary evaluation of [67Ga]tetra phenyl porphyrin complexes as possible imaging agents. J Radioanal Nucl Chem. 
2011;288(1):17-24. doi:10.1007/s10967-010-0962-1.

17. Aboudzadeh M, Fazaeli Y, Khodaverdi H, Afarideh H. Production, nano-purification, radiolabeling and biodistribution study of [140Nd] 5,10,15,20-tetraphenylporphyrin complex as a possible imaging agent. J Radioanal Nucl Chem. 2013;295(1):105-113. doi:10.1007/s10967012-1826-7.

18. Wang AY, Lin JL, Lin WC. Studies on the porphine labeled with 99mTc-pertechnetate. $J$ Radioanal Nucl Chem. 2010;284:21-28. doi:10.1007/s10967-010-0466-z.

19. Murugesan S, Shetty SJ, Srivastava TS, a.M Samuel, Noronha OPD. Preparation and biological evaluation of the new chlorin photosensitizer T3,4BCPC for detection and treatment of tumors. J Photochem Photobiol B Biol. 2002;68(1):33-38. doi:10.1016/S1011-1344(02)00329-9.

20. Santos PM, Laranjo M, Serra AC, et al. Evaluation of a 99mTc-labelled mesobisphenylporphyrin as a tumour image agent. J Label Compd Radiopharm. 2014;57(3):141147. doi:10.1002/jlcr.3180.

21. Whelan HT, Kras LH, Ozker K, et al. Selective incorporation of 111In-labeled PHOTOFRIN by glioma tissue in vivo. J Neurooncol. 1994;22(1):7-13. doi:10.1007/BF01058350.

22. Bases R, Brodie SS, Rubenfeld S. Attempts at tumor localization using $\mathrm{Cu}$ 64-labeled copper porphyrins. Cancer. 1957;11:259-263.

23. Ranyuk ER, Cauchon N, Ali H, Lecomte R, Guérin B, Van Lier JE. PET imaging using 64Culabeled sulfophthalocyanines: Synthesis and biodistribution. Bioorganic Med Chem Lett. 2011;21(24):7470-7473. doi:10.1016/j.bmcl.2011.09.121.

24. Fazaeli Y, Jalilian AR, Amini MM, et al. Preparation, nano purification, quality control and labeling optimization of [64Cu]-5,10,15,20-tetrakis (penta fluoro phenyl) porphyrin complex as a possible imaging agent. J Radioanal Nucl Chem. 2013;295(1):255-263. doi:10.1007/s10967012-1885-9.

25. Tamura M, Matsui H, Hirohara S, et al. Selective accumulation of [62Zn]-labeled glycoconjugated porphyrins as multi-functional positron emission tomography tracers in cancer cells. Bioorganic Med Chem. 2014;22(8):2563-2570. doi:10.1016/j.bmc.2014.02.021.

26. Chen Y, Sajjad M, Wang Y, Batt C, Nabi H a., Pandey RK. TSPO 18 kDa (PBR) targeted photosensitizers for cancer imaging (PET) and PDT. ACS Med Chem Lett. 2011;2:136-141. doi:10.1021/ml100211g.

27. Pandey SK, Sajjad M, Chen Y, et al. Compared to Purpurinimides, the Pyropheophorbide Containing an Iodobenzyl Group showed Enhanced PDT Efficacy and Tumor Imaging (124IPET) Ability. Bioconjug Chem. 2009;20(2):274-282. doi:10.1021/bc8003638.Compared.

28. Bryden F, Savoie H, Rosca E V, Boyle RW. PET/PDT theranostics: synthesis and biological evaluation of a peptide-targeted gallium porphyrin. Dalt Trans. 2015;44(11):4925-4932. doi:10.1039/C4DT02949F.

29. Zoller F, Riss PJ, Montforts FP, Kelleher DK, Eppard E, Rösch F. Radiolabelling and preliminary evaluation of 68Ga-tetrapyrrole derivatives as potential tracers for PET. Nucl Med Biol. 2013;40(2):280-288. doi:10.1016/j.nucmedbio.2012.11.006.

30. Fazaeli Y, Jalilian AR, Amini MM, et al. Development of a 68Ga-Fluorinated Porphyrin Complex as a Possible PET Imaging Agent. Nucl Med Mol Imaging (2010). 2012;46(1):20-26. doi:10.1007/s13139-011-0109-5.

31. Bhadwal M, Das T, Dev Sarma H, Banerjee S. Radiosynthesis and Bioevaluation of [68Ga]Labeled 5,10,15,20-Tetra(4-methylpyridyl)-porphyrin for Possible Application as a PET Radiotracer for Tumor Imaging. Mol Imaging Biol. 2014;17(1):111-118. doi:10.1007/s11307014-0760-1. 
32. Stummer W, Pichlmeier U, Meinel T, Wiestler OD, Zanella F, Reulen HJ. Fluorescence-guided surgery with 5-aminolevulinic acid for resection of malignant glioma: a randomised controlled multicentre phase III trial. Lancet Oncol. 2006;7(5):392-401. doi:10.1016/S14702045(06)70665-9.

33. Khan KU, Roohi S, Rafi M, Zahoor R, Ahmad M. Evaluation of labelling conditions, quality control and biodistribution study of 99mTc-5-aminolevulinic acid (5-ALA): a potential liver imaging agent. J Radioanal Nucl Chem. 2014;300(1):225-228. doi:10.1007/s10967-014-30144.

34. Suzuki M, Takashima-Hirano M, Ishii H, et al. Synthesis of 11C-labeled retinoic acid, [11C]ATRA, via an alkenylboron precursor by $\operatorname{Pd}(0)$-mediated rapid C-[11C] methylation. Bioorganic Med Chem Lett. 2014;24(15):3622-3625. doi:10.1016/j.bmcl.2014.05.041.

35. Jelercic S, Rajer M. The role of PET-CT in radiotherapy planning of solid tumours. Radiol Oncol. 2015;49(1):1-9. doi:10.2478/raon-2013-0071.

36. Niyazi M, Geisler J, Siefert A, et al. FET-PET for malignant glioma treatment planning. Radiother Oncol. 2011;99(1):44-48. doi:10.1016/j.radonc.2011.03.001.

37. Nowosielski M, DiFranco MD, Putzer D, et al. An intra-individual comparison of MRI, [18F]FET and [ 18F]-FLT PET in patients with high-grade gliomas. PLoS One. 2014;9(4). doi:10.1371/journal.pone.0095830.

38. Karakullukcu B, Van Veen RLP, Aans JB, et al. MR and CT based treatment planning for mTHPC mediated interstitial photodynamic therapy of head and neck cancer: Description of the method. Lasers Surg Med. 2013;45(August):517-523. doi:10.1002/1sm.22174.

39. Stockhammer F, Misch M, Horn P, Koch A, Fonyuy N, Plotkin M. Association of F18-fluoroethyl-tyrosin uptake and 5-aminolevulinic acid induced fluorescence in gliomas. Acta Neurochir (Wien). 2009;(151):1377-1383. doi:10.1007/s00701-009-0462-7.

40. Ewelt C, Floeth FW, Felsberg J, et al. Finding the anaplastic focus in diffuse gliomas : The value of Gd-DTPA enhanced MRI , FET-PET , and intraoperative , ALA-derived tissue fluorescence. Clin Neurol Neurosurg. 2011;113(7):541-547. doi:10.1016/j.clineuro.2011.03.008.

41. Cornelius JF, Steiger HJ, Stoffels G, Galldiks N, Langen KJ. 5-Aminolevulinic Acid and 18 FFET-PET as Metabolic Imaging Tools for Surgery of a Recurrent Skull Base Meningioma. $J$ Neurol Surg Part B. 2013;74:211-216.

42. Roessler K, Becherer A, Donat M, Cejna M. Intraoperative tissue fluorescence using 5aminolevolinic acid (5-ALA) is more sensitive than contrast MRI or amino acid positron emission tomography (18F-FET PET) in glioblastoma surgery. Neurol Res. 2012;34(3):3-6. doi:10.1179/1743132811Y.0000000078.

43. Kratochwil C, Combs SE, Leotta K, et al. Intra-individual comparison of 18F-FET and 18FDOPA in PET imaging of recurrent brain tumors. Neuro Oncol. 2014;16(3):434-440. doi:10.1093/neuonc/not199.

44. Valdés PA, Kim A, Brantsch M, et al. \$ \$\$-aminolevulinic acid-induced protoporphyrin IX concentration correlates with histopathologic markers of malignancy in human gliomas: the need for quantitative fluorescence-guided resection to identify regions of increasing malignancy. Neuro Oncol. 2011;13(8):846-856. doi:10.1093/neuonc/nor086.

45. Liu J, Ogawa M, Sakai T, Takashima M, Okazaki S, Magata Y. Differentiation of tumor sensitivity to photodynamic therapy and early evaluation of treatment effect by nuclear medicine techniques. Ann Nucl Med. 2013;27(7):669-675. doi:10.1007/s12149-013-0734-4.

46. Tetard M-C, Vermandel M, Leroy H-A, et al. Interstitial 5-ALA photodynamic therapy and glioblastoma: Preclinical model development and preliminary results. Photodiagnosis 
Photodyn Ther. 2016;13:218-224. doi:10.1016/j.pdpdt.2015.07.169.

47. Lapointe D, Brasseur N, Cadorette J, et al. High-resolution PET imaging for in vivo monitoring of tumor response after photodynamic therapy in mice. J Nucl Med. 1999;40:876-882.

48. Byrne a T, O'Connor a E, Hall M, et al. Vascular-targeted photodynamic therapy with BF2chelated Tetraaryl-Azadipyrromethene agents: a multi-modality molecular imaging approach to therapeutic assessment. Br J Cancer. 2009;101:1565-1573. doi:10.1038/sj.bjc.6605247.

49. Smith K, Malatesti N, Cauchon N, et al. Mono- and tri-cationic porphyrin-monoclonal antibody conjugates: Photodynamic activity and mechanism of action. Immunology. 2010;132:256-265. doi:10.1111/j.1365-2567.2010.03359.x.

50. Moore J V, Waller ML, Zhao S, et al. Feasibility of imaging photodynamic injury to tumours by high-resolution positron emission tomography. Eur J Nucl Med. 1998;25(9):1248-1254. doi:10.1007/s002590050292.

51. Sugiyama M, Sakahara H, Sato K, Harada N, Fukumoto D. Evaluation of 3'-Deoxy-3'-18 F Fluorothymidine for Monitoring Tumor Response to Radiotherapy and Photodynamic Therapy in Mice. J Nucl Med. 2004;45(45):1754-1758.

52. O'Connor AE, Mc Gee MM, Likar Y, et al. Mechanism of cell death mediated by a BF 2chelated tetraaryl-azadipyrromethene photodynamic therapeutic: Dissection of the apoptotic pathway in vitro and in vivo. Int J Cancer. 2012;130:705-715. doi:10.1002/ijc.26073.

53. Fei B, Wang H, Wu C, Chiu S. Choline PET for monitoring early tumor response to photodynamic therapy. J Nucl Med. 2010;51:130-138. doi:10.2967/jnumed.109.067579.

54. Fei B, Wang H, Wu C, et al. Choline Molecular Imaging with Small animal PET for Monitoring Tumor Cellular Response to Photodynamic Therapy of Cancer. Proc SPIE. 2009;7262(726211). doi:10.1037/a0013262.Open.

55. Cauchon N, Langlois R, Rousseau J a., et al. PET imaging of apoptosis with 64Cu-labeled streptavidin following pretargeting of phosphatidylserine with biotinylated annexin-V. Eur J Nucl Med Mol Imaging. 2007;34(2):247-258. doi:10.1007/s00259-006-0199-y.

56. Subbarayan M, Häfeli UO, Feyes DK, Unnithan J, Emancipator SN, Mukhtar H. A simplified method for preparation of $99 \mathrm{mTc}$-annexin $\mathrm{V}$ and its biologic evaluation for in vivo imaging of apoptosis after photodynamic therapy. J Nucl Med. 2003;44(4):650-656.

57. Moore RB, Chapman JD, Mercer JR, et al. Measurement of PDT-induced hypoxia in Dunning prostate tumors by iodine-123-iodoazomycin arabinoside. J Nucl Med. 1993;34(3):405-411.

58. Chan WS, Brasseur N, La Madeleine C, Ouellet R, Van Lier JE. Efficacy and mechanism of aluminum phthalocyanine and its sulfonated derivatives mediated photodynamic therapy on murine tumors. Eur J Cancer. 1997;33(11):1855-1859.

59. Brasseur N, Lewis K, Rousseau J, van Lier JE. Measurement of tumor vascular damage in mice with 99mTc-MIBI following photodynamic therapy. Photochem Photobiol. 1996;64(4):702706.

60. Moore RB, Chapman JD, Mokrzanowski a D, Arnfield MR, McPhee MS, McEwan a J. Noninvasive monitoring of photodynamic therapy with 99technetium HMPAO scintigraphy. $\mathrm{Br} J$ Cancer. 1992;65(4):491-497.

61. Bérard V, Rousseau J a, Cadorette J, et al. Dynamic imaging of transient metabolic processes by small-animal PET for the evaluation of photosensitizers in photodynamic therapy of cancer. J Nucl Med. 2006;47:1119-1126. doi:47/7/1119 [pii].

62. Cauchon N, Turcotte E, Lecomte R, Hasséssian HM, Lier JE Van. Predicting efficacy of photodynamic therapy by real-time FDG-PET in a mouse tumour model. Photochem $\{\&\}$ Photobiol Sci. 2012;11(2):364. doi:10.1039/c1pp05294b. 
63. Mathews MS, Angell-Petersen E, Sanchez R, et al. The effects of ultra low fluence rate single and repetitive photodynamic therapy on glioma spheroids. Lasers Surg Med. 2009;41(8):578584. doi:10.1002/1sm.20808.

64. Lilge L, Portnoy M, Wilson BC. Apoptosis induced in vivo by photodynamic therapy in normal brain and intracranial tumour tissue. Br J Cancer. 2000;83(8):1110-1117. doi:10.1054/bjoc.2000.1426.

65. Thorek DL, Robertson R, Bacchus W a, et al. Cerenkov imaging - a new modality for molecular imaging. Am J Nucl Med Mol Imaging. 2012;2(2):163-173.

66. Gill RK, Mitchell GS, Cherry SR. Computed Cerenkov luminescence yields for radionuclides used in biology and medicine. Phys Med Biol. 2015;60(11):4263-4280. doi:10.1088/00319155/60/11/4263.

67. Liu H, Ren G, Miao Z, et al. Molecular optical imaging with radioactive probes. PLoS One. 2010;5(3). doi:10.1371/journal.pone.0009470.

68. Dothager RS, Goiffon RJ, Jackson E, Harpstrite S, Piwnica-Worms D. Cerenkov radiation energy transfer (CRET) imaging: A novel method for optical imaging of PET isotopes in biological systems. PLoS One. 2010;5(10):1-7. doi:10.1371/journal.pone.0013300.

69. Hu Z, Liang J, Yang W, et al. Experimental Cerenkov luminescence tomography of the mouse model with SPECT imaging validation. Opt Express. 2010;18(24):24441-24450. doi:10.1364/OE.18.024441.

70. Li C, Mitchell GS, Cherry SR. Cerenkov luminescence tomography for small-animal imaging. Opt Lett. 2010;35(7):1109-1111. doi:10.1364/OL.35.001109.

71. Zhong J, Tian J, Yang X, Qin C. Whole-body cerenkov luminescence tomography with the finite element SP 3 method. Ann Biomed Eng. 2011;39(6):1728-1735. doi:10.1007/s10439011-0261-1.

72. Gonzales J, Wang F, Zamora G, et al. Ultra low fluence rate photodynamic therapy: Simulation of light emitted by the Cerenkov effect . Proc os SPIE Opt Tech Neurosurgery, Neurophotonics, Optogenetics. 2014;8928:1-11. doi:10.1117/12.2041631.

73. Hartl BA, Hirschberg H, Marcu L, Cherry SR. Characterizing low fluence thresholds for in vitro photodynamic therapy. Biomed Opt Express. 2015;6(3):770-779. doi:10.1364/BOE.6.000770.

74. Celli JP, Spring BQ, Rizvi I, et al. Imaging and Photodynamic Therapy: Mechanisms, Monitoring and Optimization. Chem Rev. 2011;110(5):2795-2838. doi:10.1021/cr900300p.Imaging.

75. Ran C, Zhang Z, Hooker J, Moore A. In vivo photoactivation without "light": Use of cherenkov radiation to overcome the penetration limit of light. Mol Imaging Biol. 2012;14(2):156-162. doi:10.1007/s11307-011-0489-z.

76. Kotagiri N, Sudlow GP, Akers WJ, Achilefu S. Breaking the depth dependency of phototherapy with Cerenkov radiation and low-radiance-responsive nanophotosensitizers. Nat Nanotechnol. 2015;10(4):370-379. doi:10.1038/nnano.2015.17.

77. Hartl BA, Hirschberg H, Marcu L, Cherry SR. Activating Photodynamic Therapy in vitro with Cerenkov Radiation Generated from Yttrium-90. J Environ Pathol Toxicol Oncol. 2016;35(2):185-192. doi:10.1615/JEnvironPatholToxicolOncol.2016016903. 